\title{
Age of Iron as a Cultural Text: The Question of Apartheid and the Body
}

\author{
Shadi S. Neimneh ${ }^{1} \&$ Marwan M. Obeidat ${ }^{1}$ \\ ${ }^{1}$ Department of English, Hashemite University, Zarqa, Jordan \\ Correspondence: Shadi Neimneh, English Department, Hashemite University, Zarqa 13115, Jordan. E-mail: \\ shadin@hu.edu.jo or shadistar2@yahoo.com
}

Received: May 13, 2014 Accepted: June 3, 2014 Online Published: August 29, 2014

doi:10.5539/ells.v4n3p1 URL: http://dx.doi.org/10.5539/ells.v4n3p1

\begin{abstract}
This paper examines the interrelationship between the body and politics in J. M. Coetzee's 1990 novel Age of Iron from a cultural studies stand-point. Coetzee uses cancer as a trope for apartheid by way of suggesting the obscenity and fatality of such a system of segregation. Mrs. Curren, dying of cancer, metaphorically stands for the social and cultural cancer of South Africa under apartheid. Coetzee's work, our argument is, turns out to be relevant not only because of its approach to the socio-historical realities of South Africa under apartheid, but because of its cultural conception of the body within a postmodern frame. The body is metaphorically treated as a trope for the body politic. This way, Coetzee establishes a strong relationship between the body and a postmodern, popular culture whereby the body becomes a text inscribed with cultural meanings and serving sociopolitical ends. Against Susan Sontag's argument that illness is not a metaphor and that metaphoric thinking is not healthy for the sick in her book Illness as Metaphor, we argue that metaphoric thinking about illness, untruthful as it might be, is still an apt means of sociopolitical commentary since we look at cancer and other diseases through an unavoidable metaphorical lens.
\end{abstract}

Keywords: Coetzee, Age of Iron, fiction, apartheid, the body, cultural theory

\section{Introduction: Contextualizing Age of Iron}

As a whole, J. M. Coetzee's Age of Iron (1990) is a picture of an inner journey of an aging classics professor, Elizabeth Curren, who lives in Cape Town and witnesses the repercussion of apartheid, a system she apparently opposed only intellectually. The novel deals with varying themes like aging, the confessor as hero, inter-racial violence, and narrative representation. However, it is the theme of the body that is our focus in this article. The body is often conceived as a medium for cultural and social expression. Instead of being only a physical reality, the body has increasingly become a carrier of cultural, social, political, and historical phenomena and problems. And in a global culture that assigns much to body shape and image, the body itself emerges as a paramount artifact. Our metaphorical understanding of the body, in its health and sickness, forms the basis for our cultural approach to the body in this article. Therefore, we examine the diseased body (the cancerous one in particular) to expose and unravel our collective understanding of disease. Our assumption is that the political adaptation of the body is part of the body's cultural and social import within a postmodern context in which the body signifies beyond itself.

J. M. Coetzee's Age of Iron (henceforth abbreviated as $A I$ ) (1990) presents a female narrator, Mrs. Curren, in the tradition of his other female narrators: Magda in In the Heart of the Country (1978) and Susan Barton in Foe (1986). The novel, as the title indicates, describes a period of political unrest between 1986-9 in Cape Town, South Africa. This period was characterized by a violent resistance of the black youth in response to the State's apartheid policies. Coetzee apparently continues in this novel an earlier preoccupation with the social, psychological, and political impact of the apartheid regime on individuals, a theme developed succinctly in Life and Times of Michael K (1983). However, Coetzee focuses more in this novel on the white South African intellectual and humanist-as represented in the figure of Mrs. Curren — rather than on the stance of the oppressed as he did in the case of Michael K.

Mrs. Curren is dissatisfied with South Africa's politicians, whom she calls using insect metaphors "a locust horde, a plague of black locusts infesting the country, munching without cease, devouring lives" (p. 28). Significantly, Mrs. Curren also uses common disease imagery to criticize the politics of her country, as indicated 
in her choice of "plague," "infesting," and "devouring." As the novel's title suggests, Mrs. Curren confronts the "age of iron" effected by apartheid, one of apathy and private pain. Apartheid results in feelings of rage and injustice among its victims. Therefore, the political orientation of the novel, of its iron age, is not hard to detect even though it is vented from the pacifist perspective of an old, dying woman.

In addition to the liberal humanist stance of Mrs. Curren, Coetzee deals with alterity figures. The oppressed other figures in $A I$ in the tramp Vercueil. While Michael $\mathrm{K}$ is a simple hare-lipped gardener fleeing the apartheid regime, Vercueil is a reticent vagrant with a disfigured hand and living amidst apartheid. In the course of this article, we will focus primarily on the dilemma of Mrs. Curren and its ramifications. In particular, we examine the diseased body as a cultural text that signifies the external circumstances of violence and oppression. In other words, we shall examine the interrelationship between the body and the political realities of space the body is placed in. In fact, many critics of literature and culture began to focus on space and the interrelationship between the private sphere of the body and the public sphere of politics and socioeconomic conditions. Critics speak of the "geography/place of the body" and view it as "a unique kind of space" (Gandal et al., 2002, p. 3). The body is, in a way, taken to figuratively represent space outside its contours. Apartheid, we should remember, is basically assigning places for whites different from those assigned for blacks. It is, in a sense, a geographical experience related to space where each is kept away from the space of "the other," to borrow Edward Said's expression in Orientalism.

Mrs. Curren, a retired Classics lecturer, writes an extended letter to her self-exiled daughter who fled the apartheid regime to America. While the daughter fled the space of apartheid, the mother inhabited it, and it figuratively lived inside her as well. The letter is begun on the day Mrs. Curren is diagnosed with terminal bone cancer. On that same day, Mrs. Curren takes in a homeless derelict and a victim of political tension, Vercueil, whom she entrusts with delivering her letter to her daughter. In literary depictions, Susan Sontag argues in Illness as Metaphor (1978), cancer is an "occasion finally to behave well" (p. 42). While this benevolent act reflects Mrs. Curren's belief in liberal humanism, it also implicitly shows her realization of her complicity in an unjust political and social system and her imminent doom. In this regard, Mrs. Curren is like the Magistrate in Waiting for the Barbarians (1980) who accommodates a tortured barbarian girl, only to discover later his complicity with her torturers and his alternative oppression of her. Complicity, as taking part in a crime, entails the inner manifestation of guilt and, symbolically, physical disorder in the form of disease.

Mortally sick, Mrs. Curren experiences her whole life in terms of an intense awareness of death. As a result, she abnegates her body in favor of saving her soul. For example, she asserts: "I am trying to keep a soul alive in times not hospitable to the soul" (p. 130). She triggers in our minds a recurrent theme in Coetzee: a troubled relationship with the body. While Magda in In the Heart of the Country is trapped in a spinster's body and experiences hallucinations and sexual fantasies of rape and incest, the barbarian girl in Waiting for the Barbarians has to deal with a tortured body of broken ankles and bruised eyes. Michael $\mathrm{K}$ in Life and Times of Michael $K$ has a harelip and a gaping left nostril. Paul Rayment in Slow Man (2005) has to come to terms with his new life as an amputee due to a bicycle accident. The problematic of the body in Coetzee, however, is not always allied to politics as it is in $A I$. Mrs. Curren in $A I$, as mentioned earlier, suffers from a terminal bone cancer that makes her sick body an intensified lived reality. The setting of the novel is that of street violence where young black militants are engaged in a struggle with security forces over power. Between the private experience of Mrs. Curren's pain and the external unrest around her, we have the full gamut of the cultural understanding of disease elaborated in this article. The associations we make are supported by Mrs. Curren's own understanding of the symptomatic nature of her illness. In fact, Coetzee's choice of a female narrator should not be politically problematic. The use of a white female narrator, an Afrikaner, is indicative of his "tendency to identify with the position of white women as both complicit with, and victimized by, patriarchal and colonial institutions like those of apartheid and literary production" (Wright, 2008, p. 13). As a woman, Mrs. Curren is closer to the experiences of the victims of apartheid. After all, apartheid is a masked form of colonization a woman like Mrs. Curren can relate to. Describing the empty impact of her words on a militant black youth, she observes the following: "The words of a woman, therefore negligible; of an old woman, therefore doubly negligible; but above all of a white" (p. 79). Mrs. Curren articulates the double form of colonization women can experience within oppressive cultures, patriarchy and apartheid in this case.

In fact, Susan Sontag in Illness as Metaphor resists thinking about the cancer personality as a cause of the disease. According to Sontag, cancer is not caused by a shy or repressed personality. Metaphorical thinking about disease does not help patients or their families deal with the disease. Nor does it necessarily speed up recovery in Sontag's argument. However, metaphorical thinking is essential to our understanding of disease. Illness does not exist apart from a sociocultural context. Nor is it an apriori concept. It is rooted in experience and cultural, 
communal understanding. The societal conception of illness is indispensable to the ill and their relatives and friends. Although from a medical viewpoint cancer myths and metaphors are not helpful to the patients, they are apparently useful to literary critics and cultural theorists. And although Sontag primarily argues against the myths and metaphors of TB and cancer, her essay remains a cornerstone record of such metaphors. Highly relevant here are the associations she makes between the body and politics. For example, Sontag argues that"[d]isease imagery is used to express concern for social order..." and illness has often been used as a metaphor for a society that is "corrupt and unjust" (p. 72). Cancer, Sontag reiterates, is one disease used to vent a "sense of dissatisfaction with society" (p. 73). The physical body in this sense is tantamount to the body politic. Sontag argues: "Order is the oldest concern of political philosophy, and if it is plausible to compare the polis to an organism, then it is plausible to compare civil disorder to an illness" (p. 76). Cancer in political discourse, Sontag adds, implies violence and fatalism (p. 83) and is fittingly viewed as "an evil, invincible predator" (p 7).Sontag argues that cancer, as a mysterious, malevolent disease, is thought to be "morally, if not literally, contagious" (p. 6). Based on this logic, injustice and corruption seem a thriving environment for cancer, the metaphorical cancer of bad politics.

As Belinda Clayton (2002) puts it, discussing the social construction of disease, "organic disruption does not constitute ill health prior to the social meaning it is given" (p. 838). Clayton adds: "Ill health can only be defined against a cultural construction of health" (p. 847). We glean from Sontag and Clayton that the body is socially constructed and inscribed with meaning. Regardless of their truth value or efficacy, metaphors are essential to our understanding of the body. The overlap between the body and language/discursive construction is essentially a postmodern concern with the body as a text and the text as a body. The next section better clarifies the political potential of the body whereby the body becomes a medium for the political inscription of oppression. In this light, the diseased body is also a text, a postmodern artifact that carries and communicates culturally-specific meanings.

\section{Age of Iron: The Body vs. the Body Politic}

In the midst of political turmoil related to resistance against apartheid policies by black youths, Coetzee highlights in the depiction of Mrs. Curren the interrelationship between a diseased country and a diseased (female) body. Mrs. Curren experiences her cancer as a result of internalizing feelings of shame and guilt accruing from what is happening around her: teenagers carry arms and go to their death fearlessly; family relations between parents and children are disintegrating; racial discrimination abounds; the police are corrupt; and love and tolerance are dwindling. Addressing her daughter, Mrs. Curren explicitly states the role of a diseased social reality in the development of her cancer. She tells the militant John, the black friend of her housekeeper's son Bheki, by way of speaking against such youth dying in comradeship and articulating the metaphorics of the relationship between the body and the body politic: "You know I am sick. Do you know what is wrong with me? I have cancer. I have cancer from the accumulation of shame I have endured in my life. That is how cancer comes about: from self-loathing the body turns malignant and begins to eat away at itself' (p. 145) Sontag refers to the common association of cancer with shame and hatred by claiming that it is thought to be "obscene" and "ill-omened, abominable, repugnant to the senses" (p. 9). Mrs. Curren takes cancer to be the metaphorical inscription of corrupt apartheid politics on her body. She says: "Perhaps I should simply accept that that is how one must live from now on: in a state of shame. Perhaps shame is nothing more than the name for the way I feel all the time" (p. 86). Shame is indicative of the political disgrace that is apartheid. In articulating shame and self-hatred as the potential causes of her cancer, Mrs. Curren appeals to the myth of the cancer personality and the psychopathological roots culturally attributed to most of the epidemics of our era. In this line of thought, a guilty, stricken conscience conspires against a vulnerable body to effect a cancerous state.

The linkage between shame as manifested in a cancerous body and complicity in political oppression is not new in Coetzee. For example, the magistrate in Waiting for the Barbarians thinks that his office as an imperial magistrate brings him necessary shame: "'When some men suffer unjustly,' I said to myself, 'it is the fate of those who witness their suffering to suffer the shame of it"' (p. 152). Similarly, Mrs. Curren tells Vercueil: "Like every crime it had its price. That price, I used to think, would have to be paid in shame: in a life of shame and a shameful death, unlamented, in an obscure corner. I accepted that. I did not try to set myself apart. Though it was not a crime I asked to be committed, it was committed in my name" (p. 164). The crime of apartheid is part of her heritage. As she reasons, "It is part of me, I am part of it" (p. 164). Shame is also caused by her feeling of complicity with the oppressors. According to the mythology of cancer-Sontag argues - it is "generally a steady repression of feeling that causes the disease" (p. 22). Cancer is a disease associated with "resignation" and lack of hope (Sontag, pp. 23-24). In fact, Mrs. Curren's terminal bone cancer can suggest the desperate, unredeemable politics of her country under apartheid. The mastectomy she underwent as a cancer patient also evokes a 
comparison between the human organism and the deformed apartheid state. Sterility is a common fate for both.

In this fictional depiction of cancer, the disease, it seems and contrary to Sontag's argument that cancer often reduced real life patients to a state of silence and disgrace, allows Mrs. Curren to vent her emotional and psychological state. In real-life scenarios, Barbara Clow (2001) argues, cancer did not reduce many patients to such a state of silence and disgrace (p. 294). Although Mrs. Curren does articulate an experience of shame as the cause of her disease, she feels free to express her state of disgrace. She is not silenced by the disease. On the contrary, the disease in her case is an occasion for self-expression. As Lawrence Thornton (1990) put it in a review of the novel, Mrs. Curren "awakens to her own complicity with South Africa's regime after years of silence" (my emphasis). In an attempt to feel with the victims of suffering in violent townships, Mrs. Curren has to "empathize" with the victims, to feel their pain through her own cancer pain. Moreover, she has to express the pain of the other in her own language. Chielozona Eze (2011) captures the allegorical and metaphorical nature of Mrs. Curren's pain and argues that "Mrs. Curren's pain is a reflection of the misery everywhere around her, the pain that has resulted from her newfound empathy for those whose lives are wasting and being wasted" (p. 30). This should not mean, Eze argues, that we can "fully appropriate another's experience of pain" (p. 31). Mrs. Curren, an intellectual, remained distant from apartheid realities. Although she might have opposed them emotionally and intellectually, she has to face them now closely by witnessing burning and shooting in violent townships.

When Mrs. Curren says "This is the worst thing I have witnessed in my life....Now my eyes are open and I can never close them again" (pp. 102-3), she juxtaposes her own physical pain against the close proximity of oppression she is witnessing. She sees the dead body of Bheki and other youths killed and lying in the rain (p. 102). In spite of "the governing conceit of her authorial mastery over the text, Coetzee ruins the story of Elizabeth Curren's authorial 'I' by showing how it is tethered to the biopolitical histories of South Africa in which she is complicit" (Walsh, 2010, p. 170). The pain of apartheid victims in townships is very close to Mrs. Curren's own bodily pain, which shortens the gap between the metaphorical nature of pain and its literal level. Although we allegorically understand Mrs. Curren's pain against apartheid politics, the pain she encounters and bears witness to is real. This pain has an authority over her narrative. In an interview with David Attwell (1992) in Doubling the Point, Coetzee argues: "Whatever else, the body is not 'that which is not,' and the proof that it isis the pain it feels. The body with its pain becomes a counter to the endless trials of doubt" (emphasis original; $p$. 248). The body exists beyond language and metaphors, but it is through language that we can hope to culturally communicate pain and disease. The mediation of the body in language is in line with postmodern and post-structuralist notions about language as our ultimate reality. Theorizing about apartheid is different from witnessing its atrocities and vicariously living them through cancer. As Coetzee contends, Mrs. Curren's authorities, "the authority of the dying and the authority of the classics" are "denied and even derided in her world" (Doubling, p. 250). The perpetrators of apartheid policies have no respect for the sanctity of human life, and the opponents of apartheid have more important things than classical wisdom.

As a white liberal humanist believing in the ideals of humanism and equality, Mrs. Curren feels a direct relationship between her psychic and physical health. Therefore, she views her cancer as a manifestation of a diseased psyche caused by her milieu. She, thus, seeks redemption from the deteriorating state of her country. She finds a possible salvation clue in the healing power of love. She tries to love an "unlovable" revolutionary black youth named John. She tells her distant daughter: "That is the first step: that I know. I must love, first of all, the unlovable. I must love, for instance, this child" (p. 136). Just as she accepts the other in the figure of Vercueil, she has to do well by loving violent youths who resist apartheid. Love counters the shame and the self-loathing she feels. It counters hatred and separation as the foundations of apartheid.

Coetzee probably uses Mrs. Curren as a generalized image of a society sick within and carrying the seeds of its self-destruction. Mrs. Curren is metaphorically pregnant with her death in the manner her country is pregnant with its own destruction and violence. Disease is commonly viewed in literary representations as effecting a dissolution or disintegration of the body. In the case of cancer, malign cells proliferate in the body, gnaw at its organs, and make it hollow. In metaphorical terms, this is the situation of South Africa under apartheid Coetzee depicts in one of his most realist novels: young people are shot by the police, people are burning schools and books, and homeless vagrants are roaming the streets. If the body politic is at fault, then physical health is at stake. Mrs. Curren describes pain in metaphorically aggressive terms that culturally construct her body: "An attack: it was just that: the pain hurling itself upon me like a dog, sinking its teeth into my back" (p. 10). Mrs. Curren understands her disease in a way that makes cancer a politically fit metaphor. Aside from fatality, cancer is viewed as an aggressive attack on the body, an invasion of the body by alien cells. It is one that occupies the body. As Sontag puts it, "Metaphorically, cancer is not so much a disease of time as a disease or pathology of 
space. Its principal metaphors refer to topography (cancer 'spreads' or 'proliferates' or is 'diffused'; tumors are surgically 'excised'), and its most dreaded consequence, short of death, is the mutilation or amputation of part of the body" (pp. 14-15). Cancer colonizes the body just as apartheid is a form of sprawling colonization. It is also an "attack" or "invasion" as cancer cells "invade" the body (p. 64). Therefore, military metaphors are often used in the analysis and treatment of cancer. Cancer is thought of in terms of warfare and battle. The disease is the occupation of the body by alien cells. It is, Sontag argues, "the ultimate insult to natural order" (p. 68). It is seen, Sontag adds, as "a disease of the contamination of the whole world" (p. 71). The dominant cultural images of cancer are particularly negative, which justifies their political orientation when it comes to appropriating space and corrupting morals.

Mrs. Curren deems her diseased body as the source of betrayal, something akin to the political treason affiliated with apartheid: "What do I care for this body that has betrayed me? I look at my hand and see only a tool, a hook, a thing for gripping other things. And these legs, these clumsy ugly stilts: why should I have to carry them with me everywhere? .... What have they to do with me?" (pp. 12-13). Above all, she has bone cancer that marks her body from inside and allegorically testifies to a material history of bodily violations in the South Africa of her times. She states: "The bones prized above all by archaeologists, I remember, are those gnarled with disease or splintered by an arrowhead: bones marked with a history from a time before history" (p. 23). Disease allegorically stands for historical injustice, which is the metaphorical treatment of cancer with relation to apartheid. Mrs. Curren herself alludes to allegorical readings by saying that her journey with Florence and her daughters Hope and Beauty to the black township of Guguletu was "like living in an allegory" (p. 90). Nevertheless, David Hoegberg (1998) rightly argues that "In this hell of human creation physical suffering is not an allegory of a future spiritual state but a brute fact" (p. 32). Burning, destruction, killing, and poverty are real and immediate to Mrs. Curren. It is our understanding of Mrs. Curren's cancer with relation to historical injustice that is aptly metaphorical and allegorical.

She once answers the apartheid police that the pain comes from her heart, that her cancer is that of the heart, one she got by "drinking from the cup of bitterness" (p. 156). What touches her body also touches the soul she tries to redeem, and the cancer outside finds its echo in the cancer within her body: "I am trying to keep a soul alive in times not hospitable to the soul" (p. 130). The times inhospitable to the soul are those of political unrest deforming human beings and affecting their emotional/physical well-being. In a pivotal text, Mrs. Curren describes her cancer in metaphorically and politically suggestive terms as an obscene pregnancy caused by first indifference to the pain of others and then internalizing the effects of such apathy:

For twenty years I have not bled. The sickness that now eats at me is dry, bloodless, slow and cold, sent by Saturn. There is something about it that does not bear thinking of. To have fallen pregnant with these growths, these cold, obscene swellings; to have carried and carried this brood beyond any natural term, unable to sate their hunger: children inside me eating more every day, not growing but bloating, toothed, clawed, forever cold and ravenous. Dry, dry: to feel them turning at night in my dry body, not stretching and kicking as a human child does but changing their angle, finding a new place to grow. Like insect eggs laid in the body of a host, now grown to grubs and implacably eating their host away. My eggs, grown within me. (p. 64)

Sontag also refers to cancer as fatal, as a "lethal growth" (p. 12), and discusses it as pregnancy: "Cancer is degeneration, the body tissues turning to something hard" (p. 13). This bodily hardening as a cancer myth is reminiscent of the iron in the novel's title. Cancer is also viewed by Sontag as "a demonic pregnancy" (p. 14). Interestingly, Mrs. Curren constructs her body in line with common myths and metaphors about cancer and against Sontag's claim that illness is more of a literal state best dealt with away from negative metaphors. In Sontag's essay, the metaphors of TB and cancer actually appropriate the text against the writer's intention of countering them.

For Mrs. Curren, cancer resembles its original meaning: the Greek word "karkinos" meaning "crab" because the cancer tumors were thought to resemble crabs ("In Search of Cancer in Literature", 2011). As a sick woman seeking salvation from political corruption outside and a corresponding infestation within her body, she considers purgation by fire as necessary for a clean start from apartheid. Fire is a cleansing force against the filth and abomination metaphorically associated with cancer. Mrs. Curren speaks of cancer cells as secret sharers, as the voice of a guilty conscience in need of purgation. Cancer is, metaphorically, her earthly purgatory:

Death by fire the only decent death left. To walk into the fire, to blaze like tow, to feel these secret sharers cringe and cry out too, at the last instant, in their harsh unused little voices; to turn and be gone, to be rid of, to leave the world clean. Monstrous growths, misbirths: a sign that one is beyond one's terms. This country 
too: time for fire, time for an end, time for what grows out of ash to grow. (p. 65)

Significantly, the fire outside is that of township violence. Death by fire for her counters the fire of such violence. It is as if fire is an extinguisher for fire. Mrs. Curren complains: "The country smolders, yet with the best will in the world I can only half-attend. My true attention is all inward, upon the thing, the word, the word for the thing inching through my body. An ignominious occupation, and in times like these ridiculous too, as a banker with his clothes on fire is a joke while a burning beggar is not" (p. 39). Mrs. Curren not only articulates the metaphorical equivalence between the diseased body and language but she also hints at the relationship between cancer and politics. The word "cancer" mediates the actual disease in language and discourse. Although Mrs. Curren views the allegorical/metaphorical relationship between her sick body and the body politic a "ridiculous" one, such a relationship is insightful for cultural theorists of the body.

Cancer for her is "a child inside that [she] cannot give birth to. Cannot because it will not be born.Because it cannot live outside [her].So it is [her] prisoner or [she] is its prisoner" (p. 82). Mrs. Curren underscores the transgressive nature of cancer as disruptive of boundaries; she claims, metaphorically, that she is emptied or eaten from within: "I am hollow, I am a shell. To each of us fate sends the right disease. Mine a disease that eats me out from inside. Were I to be opened up they would find me hollow as a doll, a doll with a crab sitting inside licking its lips, dazed by the flood of light" (p. 112). The idea here is that disease can fit a personality type or the patient's character within cultural conceptions of illness as a fit punishment. "Psychological theories of illness" Sontag argues "are a powerful means of placing the blame on the ill. Patients who are instructed that they have, unwittingly, caused their disease are also being made to feel that they have deserved it" (p. 57). The hollowness Mrs. Curren speaks of can be interpreted as the moral and ethical emptiness of apartheid politics. Because apartheid depraves both victims and victimizers, it has a hollowing (and harrowing) effect on individuals. As Sontag argues, "With the modern diseases (once TB, now cancer), the romantic idea that the disease expresses the character is invariably extended to assert that the character causes the disease-because it has not expressed itself" (p. 46). Repression of feelings is said to cause illness. Certain personality types are thought to bring upon people certain diseases. Such metaphorical thinking about illness, scientifically suspect as it might be, remains convenient for cultural and literary critics of body theory. A cancerous body, we are inclined to believe, brings together political and binary images of repression/oppression, colonization/violation, and aggression/transgression.

\section{Conclusion: Narrating the Body}

The associations Mrs. Curren makes between her emotional state and her physical condition are hardly new. Nowadays, tension and stress are highlighted by physicians as the common causes of most diseases. Mrs. Curren uses a punitive conception of cancer as a lethal disease, as a killer that arrests an unwitting victim. Since cancer is used, Sontag argues, as a metaphor for "evil" (p. 59), it can figure social disorder, i.e. "the ills of the modern era" (p. 59). We have already argued the biopolitics of cancer, its metaphorical aptness for social ills and corrupt politics. Here we would like to reassert our thesis contra Sontag's claim that illness is not a metaphor. Then we want to assert the cultural thrust of illness narratives in literature.

Sontag concedes that "Cancer was never viewed other than as a scourge; it was, metaphorically, the barbarian within" (p. 61). The barbarian without can be extended to include not only social but also political ills and historical occurrences. The novel metaphorically offers a sequential cluster of physical, moral, and sociopolitical likeness and shared characteristics linking the disavowal of the human being and the absence of sociopolitical health in the human community of Cape Town under apartheid. This way, the physical darkness of disease versus that of the sociopolitical apartheid and racism of black and white is linked to the crippled aging body living in a morally devastated country. The weakness of the body mirrors the fragility of the human community, since, logically, individual bodies interact within space and constitute the social body we call society.

It is almost impossible to discuss diseases without bringing in a host of metaphors and cultural associations. In fact, Sontag herself remained committed to the inescapability of metaphorical thinking in the sequel to her book published almost a decade later and discussing the AIDS epidemic and the fears woven around it (Illness as Metaphor and AIDS and ItsMetaphors). Illness is a metaphor, which is why Sontag discussed it at length as such. Our cultural understanding of health and disease revolves around fantasies and metaphorics. While such metaphors can be detrimental and baseless, they also help us come to terms with illness and discourse about it. It is actually part of our respect to patients to hear their stories and private experiences of pain. Narrating illness is in itself an act of constructing the diseased body and arraying it with metaphors since metaphors are, in turn, inherent to language.

If Coetzee's work is relevant to cultural critics, it is not simply because of its unconventional (or as commonly 
viewed "evasive") treatment of apartheid and South African politics. Coetzee discusses the political in terms of the cultural and vice versa. His vision is an inclusive postmodern one whereby the logic of both/and negates that of the exclusive either/or one. The body is closely aligned with the body politic, the material and historical conditions in which it exists; it ambivalently wavers, within representation, between the ineluctably material and the discursively formed. Coetzee strikes a balance between bodily pain and the ultimate construction of such experience in language. The novel is Mrs. Curren's anguished mediation of her experiences in the form of a confessional letter. She sends her body in words for her daughter to read and taste:

So day by day I render myself into words and pack the words into the page like sweets: like sweets for my daughter, for her birthday, for the day of her birth. Words out of my body, drops of myself, for her to unpack in her own time, to take in, to suck, to absorb. As they say on the bottle: old-fashioned drops, drops fashioned by the old, fashioned and packed with love, the love we have no alternative but to feel toward those to whom we give ourselves to devour or discard. (p. 9)

The letter becomes a necessary gift of love in the form of language. As Drew Leder (1990) contends, "When in pain, the body becomes the object of an ongoing interpretive quest. We obsessively probe and palpate even when this increases discomfort" (p. 78). Culture mediates the body, and language expresses its pain and anguish. Arthur Frank (1995) argues,

Ill people's storytelling is informed by a sense of responsibility to the commonsense world and represents one way of living for the other. People tell stories not just to work out their own changing identities, but also to guide others who follow them. They seek not to provide a map that can guide others - each must create their own - but rather to witness the experience of reconstructing one's own map. Witnessing is one duty to the commonsensical and to others. (emphasis original; p. 17)

Illness is an occasion for storytelling. The process of writing about illness culturally constructs the body in language in terms of common tropes. The body in Coetzee emerges as a cultural phenomenon imbued with sociopolitical leanings. And although the associations between the human body and the body politic we explore in this article may not sound totally new, our argument is that there is a significant cultural vision in Coetzee's fiction that needs to be further explored and explicated in his other fictions as well. This will lead to a revamping of Coetzee scholarship, which, in turn, will add to an already stupendous body of criticism being written on his work.

\section{References}

Clayton, B. (2002). Rethinking postmodern maladies. Current Sociology, 50(6), 839-851. http://dx.doi.org/10.1177/0011392102050006004

Clow, B. (2001). Who's afraid of Susan Sontag? or, the myths and metaphors of cancer reconsidered. Social History of Medicine, 14(2), 293-312. http://dx.doi.org/10.1093/shm/14.2.293

Coetzee, J. M. (1990). Age of Iron. New York: Random House.

Coetzee, J. M. (1992). Doubling the point: Essays and interviews (D. Attwell Ed.). Cambridge: Harvard U P.

Coetzee, J. M. (2000). Waiting for the barbarians. London: Vintage.

Eze, C. (2011). Ambits of moral judgement: Of pain, empathy and redemption in J. M. Coetzee's Age of Iron. Journal of Literary Studie, 27(4), 17-35. http://dx.doi.org/10.1080/02564718.2011.629441

Frank, A. W. (1995). The wounded storyteller: Body, illness, and ethics. Chicago: University of Chicago Press. http://dx.doi.org/10.7208/chicago/9780226260037.001.0001

Gandal, K., Giles, J., \& Obeidat, M. (2002). Redefining American spaces: The city, the land, the body, and history. American Studies International, 42(2-3), 1-11. The Fullbright American Studies Institute, Northern Illinois University, July 1-August 12, 2002.

Hoegberg, D. E. (1998).Where is hope? Coetzee's rewriting of Dante in Age of Iron. English in Africa, 25(1), $27-42$.

In search of cancer in literature. (2011). Word Search with Adair Jones. Posted Oct. 3, 2011. Nov. 5, 2013. Retrieved from http://adairjones.wordpress.com/2011/10/03/in-search-of-cancer-in literature-2/

Leder, D. (1990). The absent body. Chicago: University of Chicago Press.

Sontag, S. (1978). Illness as metaphor. New York: Farrar.

Thornton, L. (1990). Apartheid's last vicious gasps. The New York Times. A book review of Age of Iron by J. M. 
Coetzee. Sept. 23, 1990. (Sunday final section 7, page 7, column 1). Nov. 17, 2013. Retrieved from http://www.nytimes.com/books/97/11/02home/coetzee-iron.html

Walsh, R. A. (2010). 'Not grace, then, but at least the body': Accounting for the self in Coetzee's' Age of Iron. Twentieth-Century Literature, 56(2), 168-195.

Wright, L. (2008). Displacing the voice: South African feminism and JM Coetzee's female narrators. African Studies, 67(1), 11-31. http://dx.doi.org/10.1080/00020180801943073

\section{Copyrights}

Copyright for this article is retained by the author(s), with first publication rights granted to the journal.

This is an open-access article distributed under the terms and conditions of the CreativeCommons Attribution license (http://creativecommons.org/licenses/by/3.0/). 